\title{
Mechanism of transcriptional regulation of LRP16 gene expression by 17- $\beta$ estradiol in MCF-7 human breast cancer cells
}

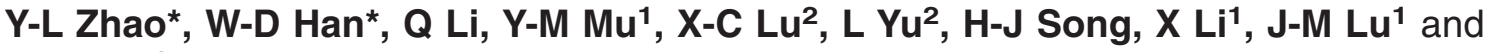 \\ C-Y Pan ${ }^{1}$
}

Department of Molecular Biology, Institute of Basic Medicine, Chinese PLA General Hospital, 28 Fu Xing Road, Beijing 100853, China

${ }^{1}$ Department of Endocrinology, Chinese PLA General Hospital, 28 Fu Xing Road, Beijing 100853, China

${ }^{2}$ Department of Hematology, Chinese PLA General Hospital, 28 Fu Xing Road, Beijing 100853, China

(Requests for offprints should be addressed to Y-M Mu; Email: muyiming@ 301 hospital.com.cn)

*(Y-L Zhao and W-D Han contributed equally to this work)

\begin{abstract}
LRP16 gene expression is induced by $17-\beta$ estradiol (E2) via estrogen receptor alpha (ER $\alpha$ ) in MCF-7 human breast cancer cells. A previous study also demonstrated that ectopic expression of LRP16 gene promoted MCF-7 cell proliferation. To explore the mechanism of hormone-induced LRP16 gene expression, the LRP16 gene promoter region ( -2600 to -24 bp upstream of the LRP16 gene translation starting site) was analyzed in the present study by using different 5 '-truncated constructs, and a luciferase reporter. The 5'-flanking sequence of -676 to -24 bp (pGL3-S5) was found to be E2-responsive. After exchange of the fragment from -213 to -24 bp with the TK gene proximal promoter region in pGL3-S5, E2 still induced reporter gene activity in MCF-7 and HeLa cells. Sequence analysis showed that the pGL3-S6 (-676 to -214) sequence contains two motifs that may contribute to E2-induced transactivation; namely, an estrogen-responsive element (ERE) half-site/Sp1 at -246 to -227 bp and an E-box site at -225 to $-219 \mathrm{bp}$. Further deletion and mutation analysis of these two motifs indicated that both the 1/2 ERE and Sp1 binding sites were required for E2 action, while E-box deletion did not affect the luciferase activity in MCF-7 and HeLa cells. The results of gel mobility shift and chromatin immunoprecipitation assays confirmed that both ER $\alpha$ and Sp1 were required for hormone-induced transactivation, which involved both $\mathrm{ER} \alpha$ and Sp1 directly binding to DNA. Taken together, these findings suggest that $\mathrm{ER} \alpha$ and Sp1 play a role in activation of the human LRP16 gene promoter.
\end{abstract}

Journal of Molecular Endocrinology (2005) 34, 77-89

\section{Introduction}

Estrogen and estrogen receptor (ER) play important roles in several physiologic processes, including development of the female and male reproductive systems as well as bone, vascular and neuronal functions (Chow et al. 1992, Turner et al. 1994, Farhat et al. 1996). They are also important pathologic factors in the genesis and malignant progression of breast cancer (Dong et al. 1999, Khan et al. 2003). ER $\alpha$ regulates the transcription of various genes as a transcription factor that binds to estrogen response elements or interacts with other transcription factors upstream of the target genes (Klinge 2001, Safe 2001, Petz et al. 2002). There are many reports concerning target genes that are transcriptionally activated by ER $\alpha$, but the entire mechanism of the pathway from ER $\alpha$ leading to the proliferation and progression of mammary tumors is far from clarified (Finlin et al. 2001, van 't Veer et al. 2002). Breast cancer cell lines have been extensively used as models for understanding the mechanisms associated with $17 \beta$ - estradiol (E2)-induced cell growth and for development of antiestrogenic and anticarcinogenic agents for treatment of this disease (Dickson \& Lippman 1995, Levenson \& Jordan 1997, Briand \& Lykkesfeldt 2001). MCF-7 cells were among the first ER-positive human breast cancer cell lines characterized as responsive to the mitogenic effects of estrogens in cell culture and in athymic nude mice bearing MCF-7 cell xenografts (Brooks et al. 1973, Soule et al. 1973, Lippman et al. 1975, Levenson \& Jordan 1997).

LRP16 is a novel gene that was cloned from human lymphocyte cells by our group in 2000, using restriction length genomic scanning (RLGS); the cDNA was then isolated by the rapid amplification of cDNA end (RACE) technique (GenBank accession no. AF202922) (Yu et al. 2000). LRP16 contains an open reading frame for a protein of 325 amino acids. Although the physiologic roles of the LRP16 gene have not been delineated, the fact that ectopic expression of the LRP16 gene stimulated MCF-7 cell proliferation suggests that LRP16 may play an important role in carcinogenesis and/or 
progression of hormone-dependent breast cancer (Han et al. 2003a,b).

Our previous studies have shown that E2 induces LRP16 gene expression and reporter gene activity in MCF-7 human breast cancer cells transiently transfected with constructs containing LRP16 gene promoter inserts linked to a reporter gene (Han et al. 2003a,b). A $2.6 \mathrm{~kb}$ fragment (upstream of the translation starting site of human LRP16 gene) that has E2 responsiveness was identified (Han et al. 2003a,b). In our previous study, the reporter gene activity was observed not only in the ER-positive MCF-7 cells, but also in the ER-negative COS-7 cells. These data suggest that the effect of E2-induced transactivation is a direct interaction between ER $\alpha$ and the promoter region of the LRP16 gene. The main purpose of the experiments reported here is to illustrate the mechanism of transcriptional regulation of LRP16 gene expression by $\mathrm{E} 2$, and to determine cis-elements present in the $2.6 \mathrm{~kb}$ fragment of human LRP16 gene promoter that confers the E2 transactivation effect. A proximal region of -676 to $-24 \mathrm{bp}$ was first found to be important for E2 action by deletion mutants. Further analysis of deletion and mutation constructs showed that either the estrogenresponsive element (ERE) half-site $(1 / 2)$ at -246 to -242 bp or the GC-rich Spl binding site at the -236 to -227 bp site was critical for E2 responsiveness in both MCF-7 and HeLa cells. Subsequently, gel mobility shift assays and chromatin immunoprecipitation assays confirmed that both ER $\alpha$ and Spl directly bind to DNA.

\section{Materials and methods}

\section{Chemicals and biochemicals}

E2, antibiotic solution, and polydeoxyinosinedeoxycytidine (poly-dIOdC) were purchased from Sigma. Fetal calf serum (FCS) and Dulbecco's Modified Eagle's Medium (DMEM) were obtained from GibcoBRL (Grand Island, NY, USA). Transfection reagent SuperFect, PCR product and plasmid extraction kits were purchased from Qiagen. $\left[\gamma^{032} \mathrm{P}\right]$ ATP was purchased from YaHui Chemical Co. (Beijing, China). The luciferase enzyme assay system, T4 DNA ligase and T4-polynucleotide kinase were purchased from Promega. LA Taq DNA polymerase and various restriction enzymes were purchased from TaKaRa (Otsu, Shiga, Japan). Spl and ER $\alpha$ antibodies were obtained from Santa Cruz Biotechnology (Santa Cruz, CA, USA). Chromatin immunoprecipitation (ChIPs) assay kits were purchased from Upstate Co. (Lake Placid, NY, USA). FCS was stripped twice with a 1:2 ratio of dextran-coated charcoal $(0.01 \mathrm{M}$ Tris-HCL, $0 \cdot 25 \%$ Nort A charcoal and $0.025 \%$ dextran, $\mathrm{pH} 8 \cdot 0$ ) at $45^{\circ} \mathrm{C}$ for $40 \mathrm{~min}$ to remove endogenous hormones. Purified ER $\alpha$ protein was obtained from PanVera Corp.
(Madison, WI, USA), and the purified Spl protein was obtained from Promega. The synthetic oligonucleotides derived from the LRP16 gene promoter, consensus Sp1 and consensus ERE oligonucleotide were synthesized by ShengGong Biotechnology (Shanghai, China). The sequences for these nucleotides (sense strands) are summarized below. The GC-rich sequences and ERE1/2 sites are underlined, E-box sites are noted by italic type, mutations are underlined and substituted bases are indicated by boldface type:

- pul, 5'-GAGCTC (SacI) GGT GAG AGC TGA GGA TAT AAC G-3'

pu2, 5'-GAGGTC (SacI) CGT CGT ACG GCG ATC CAT GG-3'

- pu3, 5'-GAGGTC (SacI) TAT ATT GGG CAG GCT GGT CTT G-3'

- pu4, 5'-GAGCTC (SacI) GCT CAG GGC AAC CTC CGC CTT C-3'

- pu5, 5'-GAGCTC (SacI) AGA TTG TGG TCG

AGG TGA GGC $-3^{\prime}$

- pd, 5'-AAGGTT (HindIII) CGG CGG AGT TGG

ACT CTA TTT-3'

- pd6, 5'-AGATCT (BglII) ATA CAC ACG TGC GGG CGC GCG-3'

- pd7, 5'-AGATCT (BglII) CGG ATG GAG CGG CGC CTG A-3'

- pd8, 5'-AGATCT (BglII) GCG CCG GCG GGG GCT CGC AGT GTC GC-3'

- pd8 ml, 5'-AGATCT (BgIII) GGG CGG G TT CGG GCT CAG AGT GTC GG-3'

- pd8 m2, 5'-AGATGT (BglII) GGG CGG GGC CGG GCT CAA AGT GTC GC-3'

- pd8 m3, 5'-AGATCT (BglII) GGG GGG GTT

CGG GCT CAA AGT GTC GC-3'

- S5p (-254 to -224), 5'-TCG GGG ACA CTG GGA GCC CGG GCG GGC GCG-3'

- consensus Spl, 5'- AGG TTA TTC GAT GGG GGC GGG GCG AGC G-3'

- Spl (mutant), 5'- AGG TTA TTG GAT CGA AGC GGG GCG AGC G-3'

- consensus ERE, 5'-GTG CAA AGT CAG GTC ACA GTG ACG TGA TCA AAG A-3'

- ERE (mutant), 5-GTG CAA AGT CAG GAC ACA GTG TGG TGA TGA AAG A-3.

\section{Plasmids}

The vectors, including pGEM-T-easy, pGL3-Basic, pRL-SV40, pGL3-GMV and pRL-TK, were purchased from Promega. A human ER $\alpha$ expression vector, ps5ER $\alpha$, was kindly provided by Dr Hajime Namata of Kyushu University, Japan. Constructs of pGL3-S (-2223 to $-24 \mathrm{bp}), \mathrm{pGL3}-\mathrm{S}_{2}(-1775$ to $-24 \mathrm{bp}), \mathrm{pGL3}-\mathrm{S} 3$ $(-1354$ to $-24 \mathrm{bp})$, pGL3-S $_{4}(-1064$ to $-24 \mathrm{bp})$ and pGL3-S ${ }_{5}$ (-676 to $\left.-24 \mathrm{bp}\right)$ were made by PCR amplification, using pGL3-S $\mathrm{S}_{0}(-2623$ to $-24 \mathrm{bp}$ ) as the 
template, and inserted into the pGL3-basic vector at SacI and HindIII cloning sites. The forward primers with SacI restriction linker used for pGL3-S 1 to

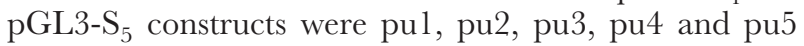
respectively, and the reverse primer with HindIII restriction linker was pd. The pGL3-TK construct was made by inserting a TK promoter, which was obtained by BgIII and HindIII enzyme digestion from a pRL-TK plasmid, into the pGL3-basic vector at the same cloning sites. pGL3-S 6 ( -676 to $-214 \mathrm{bp})$, pGL3-S 7 (-676 to $-251 \mathrm{bp}), \mathrm{pGL} 3-\mathrm{S}_{8}(-676$ to $-225 \mathrm{bp}), \mathrm{pGL} 3-\mathrm{S}_{8 \mathrm{~m} 1}(-676$ to -225 bp with GC-rich region mutation), $\mathrm{pGL3}^{-\mathrm{S}_{8 \mathrm{~m} 2}}$ (-676 to $-225 \mathrm{bp}$ with ERE1/2 mutation) and pGL3-S ${ }_{8 \mathrm{~m} 3}$ (-676 to -225 bp with both ERE1/2 and GG-rich region mutations) were made by ligation of appropriate restriction fragments into the pGL3-TK plasmid. The mutation sites were introduced through PCR primers. pu5 was used as the forward primer for

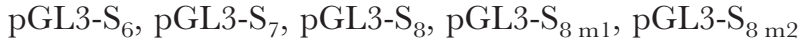
and pGL3-S $\mathrm{S}_{8 \mathrm{~m} 3}$ constructs, and pd6, pd7, pd8, pd8 $\mathrm{ml}$, pd $8 \mathrm{~m} 2$ and pd8 $\mathrm{m} 3$ were used as reverse primers for these constructs respectively. The LRP16 promoter fragments amplified by PCR were first cloned into the pGEM-T easy TA vector. All ligation products were transformed into DH5 $\alpha$-competent cells. Constructions were confirmed by restriction enzyme mapping and DNA sequencing. High-quality plasmids for transfection were prepared with the Qiagen Megaprep plasmid kit.

\section{Preparation of MCF-7 nuclear extracts}

MCF-7 cells were plated into $100 \mathrm{~mm}$ dishes and exposed to $100 \mathrm{nM} \mathrm{E2}$ for $72 \mathrm{~h}$, and then the cells were harvested and pelleted. Pelleted cells were resuspended in $1 \mathrm{ml}$ buffer A (10 mM HEPES, pH $7.9,1.5 \mathrm{mM}$ $\mathrm{MgCl}_{2}, 1.0 \mathrm{mM}$ EDTA, $10 \mathrm{mM} \mathrm{KCl}, 1.0 \mathrm{mM}$ DTT, $0.5 \mathrm{mM}$ PMSF, $100 \mu \mathrm{g} / \mathrm{ml}$ pepstain A and $100 \mu \mathrm{g} / \mathrm{ml}$ aprotinin), incubated on ice for $45 \mathrm{~min}$, homogenized and then centrifuged at $20000 \boldsymbol{g}$ for $30 \mathrm{~min}$. The nuclei were resuspended in buffer $\mathrm{B}(10 \mathrm{mM}$ HEPES, $\mathrm{pH} 7 \cdot 9$, $1.5 \mathrm{mM} \mathrm{MgCl}_{2}, 1.0 \mathrm{mM}$ EDTA, $0.5 \mathrm{M} \mathrm{KCl}, 1.0 \mathrm{mM}$ DTT, $0.5 \mathrm{mM}$ PMSF, $100 \mu \mathrm{g} / \mathrm{ml}$ pepstain A and $100 \mu \mathrm{g} / \mathrm{ml}$ aprotinin) and incubated on ice for $30 \mathrm{~min}$. The nuclear extract was centrifuged at $20000 \boldsymbol{g}$ for $30 \mathrm{~min}$, aliquoted, assayed for protein concentration and stored at $-80{ }^{\circ} \mathrm{C}$.

\section{Cell lines and culture conditions}

The HeLa and MCF-7 cells were purchased from ATCG (Rockville, MD, USA). HeLa cells were maintained in DMEM supplemented with 10\% FCS and $100 \mathrm{U} / \mathrm{ml}$ penicillin-streptomycin, while MCF-7 cells were maintained in DMEM supplemented with $10 \%$ FCS, $2 \mathrm{mM}$ L-glutamine, $10 \mathrm{mg} / \mathrm{ml}$ bovine insulin and $100 \mathrm{U} / \mathrm{ml}$ penicillin-streptomycin in a humid atmosphere with $5 \% \mathrm{CO}_{2}$ at $37^{\circ} \mathrm{C}$.

\section{Transient transfection and luciferase assay}

For transfection experiments, MCF-7 and HeLa cells were seeded in $35 \mathrm{~mm}$ culture dishes in DMEM supplemented with $1 \%$ dextran-coated charcoal FCS and grown until they were $50 \%$ confluent. Reporter plasmids $(1 \mu \mathrm{g})$ were transiently cotransfected with the $\mathrm{ER} \alpha$ expression vector $(1 \mu \mathrm{g})$ with the SuperFect reagent, according to the manufacturer's instructions. An amount of $5 \mathrm{ng}$ Renilla luciferase control vector, pRL-SV40 (as an internal standard), was added to each dish to assess the transfection efficiency. Cells were incubated for $12 \mathrm{~h}$ and then treated with $\mathrm{E} 2(100 \mathrm{nM})$ or DMSO for 34-40 h. The cells were lysed and harvested by the Dual-Luciferase reporter assay system. The luciferase activity in the lysates was analyzed with a Lumat LB 9507 (Promega). The experiments for each treatment group were carried out at least in triplicate.

\section{Gel mobility shift assays with nuclear extracts and purified proteins}

Gel mobility shift assays were carried out essentially as previously described (Xie et al. 2000). The nucleotides were synthesized, purified and annealed, and $1.75 \mathrm{pmol}$ specific oligonucleotides were ${ }^{32} \mathrm{P}$-labeled at the $5^{\prime}$-end with T4 polynucleotide kinase and $\left[{ }^{32} \mathrm{P}\right] \mathrm{ATP}$. Nuclear extracts were incubated in HEPES with $\mathrm{ZnCl}_{2}$ and $1 \mu \mathrm{g}$ polydeoxyinosine-deoxycytidine for $10 \mathrm{~min}$ on ice to remove nonspecific DNA-binding proteins. Subsequently, a 100-fold excess of unlabeled wild-type or mutant oligonucleotide competitors for the competition experiments was incubated with the nuclear extracts for $5 \mathrm{~min}$ on ice. The mixture was then incubated for $15 \mathrm{~min}$ at room temperature with the appropriate ${ }^{32} \mathrm{P}$-labeled DNA probe, and then antibodies were added for $20 \mathrm{~min}$ on ice. When purified proteins were used, ${ }^{32} \mathrm{P}$-labeled S5p probe and $200 \mathrm{fmol}$ purified ER $\alpha$ protein or $1 \mathrm{ng}$ purified Spl protein were added to the reaction mixture in the presence of $1 \mu \mathrm{g}$ polydeoxyinosine-deoxycytidine and incubated for $15 \mathrm{~min}$ at $25^{\circ} \mathrm{C}$. E2 was added to the binding reactions containing purified $\mathrm{ER} \alpha$ protein at a final concentration of $20 \mathrm{nM}$. The reaction mixture was then loaded onto a $6 \%$ polyacrylamide gel and electrophoresed at $200 \mathrm{~V}$ for $1.5 \mathrm{~h}$ in $0.5 \times \mathrm{TBE}$ buffer. The gel was dried at $60{ }^{\circ} \mathrm{C}$, and protein-DNA complexes were visualized by autoradiography.

\section{Chromatin immunoprecipitation (ChIP) assays}

MCF-7 cells $\left(1 \times 10^{6}\right)$ were grown in $10 \mathrm{~cm}$ tissue culture plates and treated with $100 \mathrm{nM}$ E2 for various times. Formaldehyde was then directly added to the medium to 
a final concentration of $1 \%$, and it was then incubated for $10 \mathrm{~min}$ at $37^{\circ} \mathrm{C}$. The medium was then completely removed, and the cells were washed twice in ice-cold PBS containing protease inhibitors $(1 \mathrm{mM}$ phenylmethylsulfonyl fluoride, $1 \mu \mathrm{g} / \mathrm{ml}$ aprotinin and $1 \mu \mathrm{g} / \mathrm{ml}$ pepstatin A). Cells were then scraped, collected by centrifugation for $4 \mathrm{~min}$ at $2000 \boldsymbol{g}$ at $4{ }^{\circ} \mathrm{C}$, resuspended in SDS lysis buffer $1 \%$ SDS, $10 \mathrm{mM}$ EDTA and $50 \mathrm{mM}$ Tris, $\mathrm{pH} 8 \cdot 1$ ) and incubated for $10 \mathrm{~min}$ on ice, and then the lysate was sonicated for $45 \mathrm{~s}$ to shear DNA to lengths of 200-1000 bp. This extract was then centrifuged at $15000 \mathrm{~g}$ for $10 \mathrm{~min}$ at $4{ }^{\circ} \mathrm{C}$, aliquoted, and stored at $-80^{\circ} \mathrm{C}$ until used. An aliquot $(4 \mu \mathrm{l})$ of salmon sperm DNA/protein A agarose-50\% slurry (Upstate Co.) was then added per $100 \mu \mathrm{l}$ chromatin and incubated for $30 \mathrm{~min}$ at $4{ }^{\circ} \mathrm{C}$ with agitation. A $100 \mu \mathrm{l}$ aliquot was saved and used as the $100 \%$ input control. The agarose was pelleted by brief centrifugation and the supernatant fraction was collected. Specific antibodies or nonspecific IgG was added, and the mixture was incubated overnight at $4{ }^{\circ} \mathrm{C}$. Subsequently, $4 \mu \mathrm{l}$ salmon sperm DNA/ protein A agarose- $50 \%$ slurry were added per $100 \mu \mathrm{l}$ chromatin and incubated for an additional $1 \mathrm{~h}$ at $4{ }^{\circ} \mathrm{C}$ with rotation. Samples were then briefly centrifuged, and the supernatant that contained unbound, nonspecific DNA was carefully removed. The protein A agarose/antibody/protein complex was incubated for 3-5 min with $1 \mathrm{ml}$ of a series of buffers provided by Upstate (ChIP Assay Kit, catalog no. 17-295). Subsequently, $250 \mu \mathrm{l}$ freshly prepared elution buffer $(1 \%$ SDS and $0 \cdot 1 \mathrm{M} \mathrm{NaHCO}$ ) were added to the pelleted protein A agarose/antibody/protein complex, the mixture was vortexed briefly to mix it thoroughly, and it was then incubated at room temperature for $15 \mathrm{~min}$ with rotation. The agarose was removed by centrifugation, and the supernatant fraction was transferred to another tube. The elution from the agarose was repeated, and the supernatant fraction was combined. An aliquot of $5 \mathrm{M} \mathrm{NaCl}(1 \mu \mathrm{l})$ was added per $20 \mu \mathrm{l}$ combined eluates and incubated at $65{ }^{\circ} \mathrm{C}$ for $4 \mathrm{~h}$ to reverse protein-DNA cross-links. Subsequently, $10 \mu \mathrm{l}$ $0.5 \mathrm{M}$ EDTA, $20 \mu \mathrm{l} 1 \mathrm{M}$ Tris-HCL $(\mathrm{pH} 6.5)$ and $2 \mu \mathrm{l}$ $10 \mathrm{mg} / \mathrm{ml}$ proteinase $\mathrm{K}$ were added to the eluates, and the mixture was incubated for $1 \mathrm{~h}$ at $45^{\circ} \mathrm{C}$. DNA was recovered by phenol/chloroform extraction and ethanol precipitation, and was resuspended in TE buffer for PGR analysis. PGR was used to detect the presence of promoter regions immunoprecipitated with ER $\alpha$ or Spl antibodies (Santa Cruz Biotechnology). The primers -356, 5'-GCGGACGCTCAGCGAACGAG-3' and -210, 5'-TGGTATAGAGGTGGGGGG-3' (LRP16 gene promoter); and 5'-GGGGTGGCTGTGAAGG TGGA-3' and 5'-CGTTGACGATGGCGTCGACG-3' (third exon in LRP16 gene, $115 \mathrm{bp}$ ) were synthesized and used for PCR analysis of the immunoprecipitated DNA.

\section{Statistical analysis}

Experiments were performed in triplicate, and the results were expressed as means \pm S.D. Statistical significance was determined by Statview and Student's $t$-test, and the levels of probability are noted for each experiment.

\section{Results}

\section{Hormonal induced transactivation study of LRP16 gene promoter region in MCF-7 cells}

Previous studies have demonstrated that E2 induces LRP16 gene expression in MCF-7 cells, and this leads to an 11-fold increase in luciferase activity in COS-7 cells transiently cotransfected with an ER $\alpha$ and pGL3-S containing a -2623 to -24 bp LRP16 gene 5 '-flanking sequence region insert (Han et al. 2003a). Interestingly, the initial transient transfection studies with a pGL3-S vector construct showed that treatment with $10 \mathrm{nM}$, $100 \mathrm{nM}$ and $1 \mu \mathrm{M}$ E2 resulted in a 2.5-, 1.5- and 2-fold increase in reporter gene activity respectively (Fig. 1). However, after cotransfection with ER $\alpha$, there was an enhanced (10-12-fold) induction of reporter gene activity after treatment with 10 and $100 \mathrm{nM}$ E2. These results are consistent with several reported transfection studies in ER-positive breast cancer cells with E2responsive constructs, which showed that enhanced hormone induction of gene expression is observed only after cotransfection with an ER $\alpha$ expression plasmid (Castro-Rivera et al. 2001, Samudio et al. 2001, Qin et al. 2002). This has been attributed to the high copy number of construct required in transfected cells where endogenous ER $\alpha$ becomes limiting, and the E2 responsiveness is enhanced by cotransfection with an $\mathrm{ER} \alpha$ expression plasmid (Augereau et al. 1994). Therefore, the ER $\alpha$ expression vector was cotransfected with the constructs of interest in all of the subsequent experiments.

To identify the essential motifs contributing to E2 action in the promoter region of pGL3- $\mathrm{S}_{0}$, we constructed a set of deletion mutants. The structures of the deletion mutants are indicated in Fig. 2A. As shown in Fig. 2B, E2-induced transactivation of the reporter gene in all six constructs, including pGL3- $\mathrm{S}_{0}$, pGL3-S 1 , pGL3-S 2 , pGL3-S 3 , pGL3-S ${ }_{4}$ and pGL3-S . Among the fragments, the promoter regions of -2623 to $-24 \mathrm{bp}$ exhibited relatively lower fold increase in luciferase activities than did the other five fragments. This observation probably indicates that the region of $-2.6 \mathrm{~kb}$ to $-2 \cdot 2 \mathrm{~kb}$ decreased E2-induced promoter activities. Furthermore, the results suggest that the promoter region of the LRP16 gene contains a possible negative regulatory sequence that influences E2 responsiveness. 


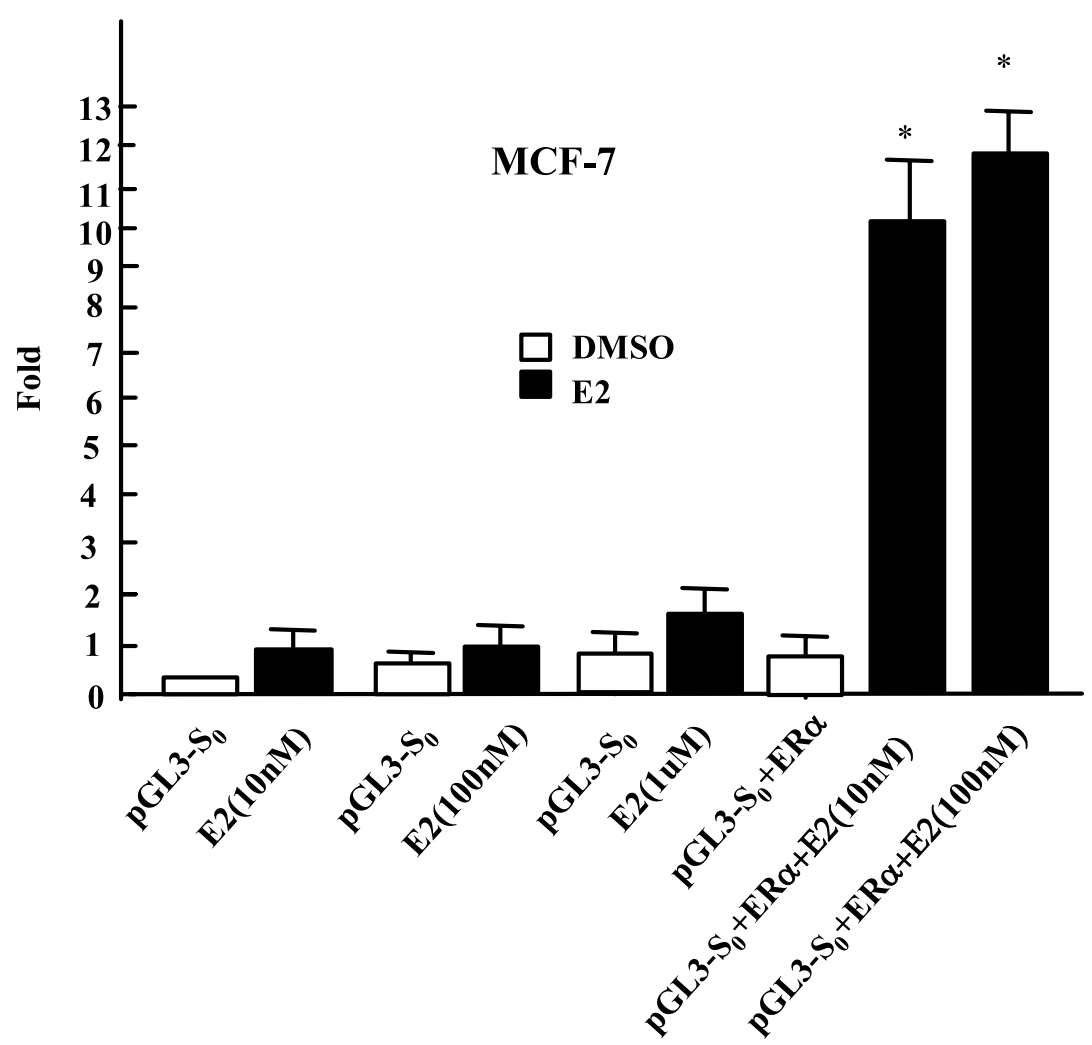

Figure 1 Hormone-induced activation of PGL3-S $\mathrm{S}_{0}$ in MCF-7 cells. Cells were transfected with PGL3-S $S_{0}$ and $1 \mu \mathrm{g}$ ER $\alpha$ expression plasmid, and the effects of E2 on luciferase activity were determined, as described in Materials and methods. Results are expressed as mean \pm S.D. for at least three triplicate determinations for each treatment group. Statistically significant $(P<0.05)$ induction is indicated by an asterisk.

Although we cannot exclude the possibility that positive elements for E2 action exist within the fragment of $-2 \cdot 6 \mathrm{~kb}$ to $-677 \mathrm{bp}$, deletion of this fragment did not affect the E2-induced transactivation activities. Therefore, we focused on the region of -676 to $-24 \mathrm{bp}$ to identify the cis-elements that may interact with ER $\alpha$. Subsequently, two 3'-deletion mutants, pGL3-S 6 (-676 to $-214 \mathrm{bp})$ and pGL3-S 7 (-676 to $-251 \mathrm{bp})$, were constructed, and the structures are shown in Fig. 3A. In these two constructs, the TK promoter from a pRL-TK plasmid was inserted into the $3^{\prime}$-terminals of these two fragments because it can provide cis-elements for general transcription factors to bind. As can be seen in Fig. 3B, E2 stimulated a fourfold increase in luciferase activity by MCF-7 cells cotransfected with pGL3-S 6 compared to the control, but not in cells cotransfected with pGL3-S . $_{7}$ These data indicate that a minimal $38 \mathrm{bp}$ sequence of -214 to $-251 \mathrm{bp}$ is indispensable for hormone responsiveness of the LRP16 gene promoter located within the -676 to $-214 \mathrm{bp}$ region. Furthermore, this was also demonstrated in the ER-negative HeLa cells (Fig. 3C).

\section{Estrogen enhances transcription of a reporter plasmid containing the ERE1/2/Sp1 binding site}

The minimal $38 \mathrm{bp}$ sequence of -214 to $-251 \mathrm{bp}$ of the human LRP16 gene promoter which contributed to E2 responsiveness, as illustrated above, contains an ERE1/2 site at -246 to $-242 \mathrm{bp}$, a GC-rich $\mathrm{Sp} 1$ binding region at -236 to -227 bp and an E-box at -225 to -219 bp (Fig. 4A). A number of studies have suggested that a Spl site alone, or in combination with imperfect ERE sites or an ERE1/2 site, may be involved in conferring estrogen responsiveness (Krishnan et al. 1994, Porter et al. 1996, Scholz et al. 1998, Sun et al. 1998, Petz et al. 2000). Xing and Archer (1998) also have demonstrated that upstream stimulatory factors may mediate estrogen receptor activation by binding to E-box sites within the proximal promoter region of E2-induced genes. To determine whether the E-box is essential for estrogen responsiveness of the LRP16 gene promoter, we deleted it in the pGL3-S $\mathrm{S}_{8}(-676$ to $-225 \mathrm{bp}$ ) construct (Fig. $4 \mathrm{~B}$ ). By transient cotransfection assay, the E2-induced transactivation activities conferred by pGL3-S 6 ( -676 to 
(A)

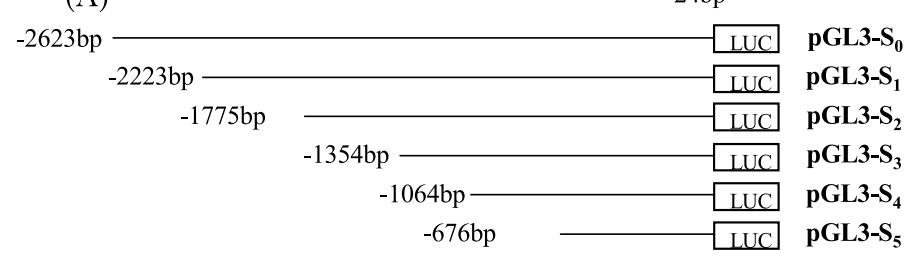

(B)

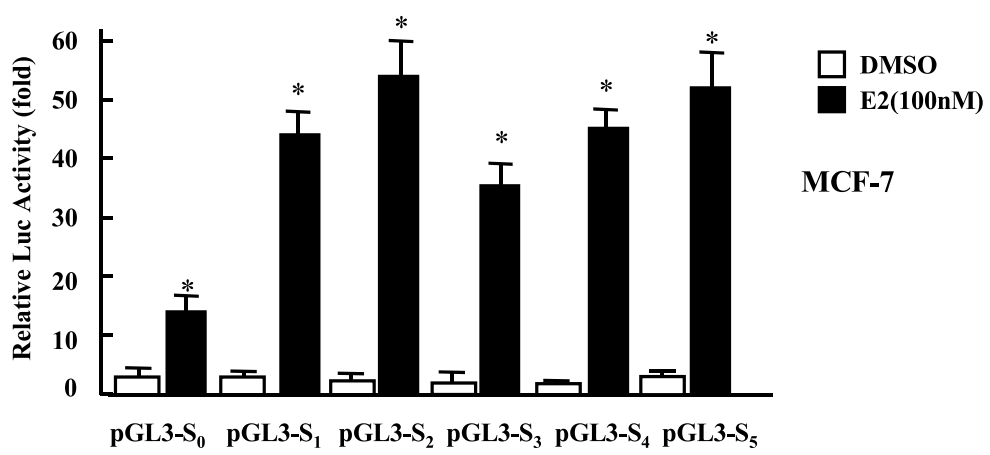

Figure 2 Luciferase assay with deletion mutants prepared from 5 '-terminal region of the human LRP16 gene in MCF-7 cells. The structure of DNA fragments with various deletions is shown on the top panel (A). The numbers indicate nucleotide positions of the $5^{\prime}$-end from the first nucleotide of the codon for initiation of translation. Each fragment was linked to the luciferase gene on the pGL3-basic vector and used for transfection experiments. The names of the luciferase plasmids are shown on the right. The results of the luciferase assays with the deletion mutants are shown on the bottom panel (B). MCF-7 cells were transiently transfected with $1 \mu \mathrm{g}$ various deletion mutants and $1 \mu \mathrm{g}$ human ER $\alpha$ expression plasmid in an individual $35 \mathrm{~mm}$ Petri dish, and treated with DMSO or $100 \mathrm{nM}$ E2. Luciferase activity was determined as described in Materials and methods. Results are expressed as means \pm S.D. for at least three triplicate determinations for each treatment group, and statistically significant $(P<0.05)$ induction is indicated with an asterisk.

$-214 \mathrm{bp})$ and pGL3-S $\mathrm{S}_{8} \quad(-676$ to $-225 \mathrm{bp})$ were compared. As shown in Fig. 4C and D, exposure to E2 led to significant increases in luciferase activity in both MCF-7 and HeLa cells cotransfected with either the pGL3-S ${ }_{6}$ or pGL3-S s $_{8}$ constructs. It was also observed that E-box deletion did not affect the reporter gene activity induced by E2. These observations indicate that the E-box is not indispensable in conferring the action of E2. However, it was not observed that the presence of the E-box inhibited the basal level of reporter gene in MCF-7 cells, as reported by Khan et al. (2003) in the CAD gene promoter system, but in HeLa cells the basal activities were only slightly increased in the absence of the E-box.

As shown above, the LRP16 promoter fragment of -251 to $-225 \mathrm{bp}$ of the human gene is significantly associated with E2-induced transactivation activity. To determine whether the functional enhancer element for conferring the E2 action is the GG-rich Spl binding site alone, or whether it also requires combination with the ERE1/2 site (ERE1/2/Sp1), we constructed a series of mutants, including pGL3-S ${ }_{8 \mathrm{~m} 1}$ (-676 to $-225 \mathrm{bp}$ with
GG-rich region mutation alone), pGL3- $\mathrm{S}_{8 \mathrm{~m} 2}$ ( -676 to -225 bp with ERE1/2 mutation alone) and pGL3-S $\mathrm{S}_{8 \mathrm{~m}}$ (-676 to $-225 \mathrm{bp}$ with both ERE1/2 and GC-rich region mutations). These structures are shown in Fig. 4B. The results of cotransfection demonstrated that mutation of both sites or either one markedly decreased the reporter gene activities induced by E2 (Fig. 4E and F). In the pGL3-S $\mathrm{S}_{8 \mathrm{~m} 2}$ cotransfection groups, treatment with E2 resulted in only 2- and 1.5-fold increases in luciferase activity in MCF-7 and HeLa cells respectively. In contrast, in the pGL3- $\mathrm{S}_{8 \mathrm{~m} 1}$ and pGL3-S $\mathrm{S}_{8 \mathrm{~m} 3}$ groups, the E2-induced transactivation activities maintained their basal levels in both cell lines. These findings suggest that both the ERE1/2 site and Spl binding sites are involved in estrogen-mediated activation of the LRP16 gene promoter.

\section{Interactions of ER $\alpha$ and Sp1 proteins with the ERE1/2/Sp1 binding site}

The transient transfection experiments provided evidence for the involvement of the ERE1/2/Sp1 binding 


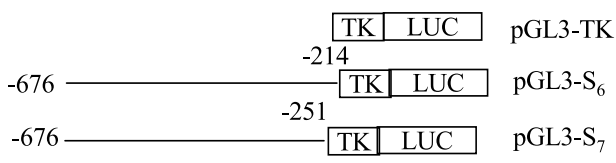

(A)

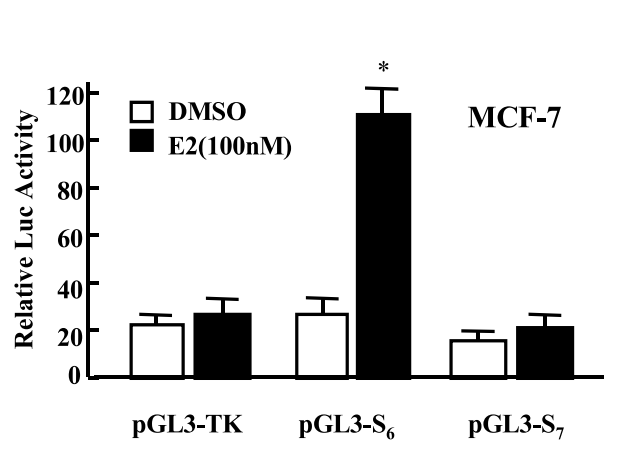

(B)

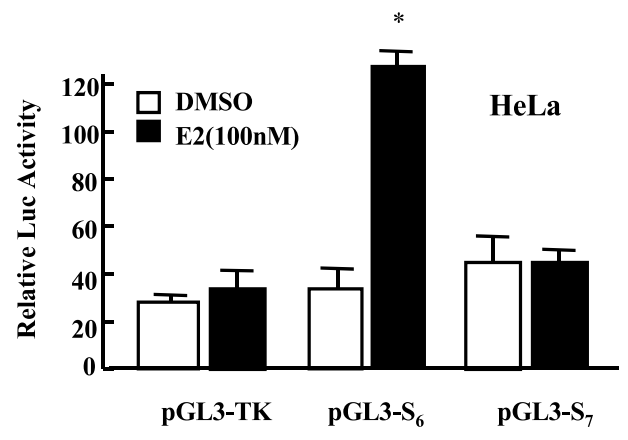

(C)

Figure 3 Effects of E2 on reporter gene activities with deletion mutants prepared from pGL3-S ${ }_{5}$ in MCF-7 and HeLa cells. The structures of the deletion mutants with 3 '-end deletion of pGL3-S5 are shown in panel A. The names of plasmids are shown on the right. The minimal promoter region of the TK gene was from the pRL-TK plasmid, and was linked to the luciferase gene on the pGL3-basic vector. The fragments prepared from pGL3-S ${ }_{5}$ were linked to the pGL3-TK plasmid. PGL3-TK was used as a negative control. Luciferase activities in MCF-7 and HeLa cells transfected with various constructs and human $\mathrm{ER} \alpha$ expression plasmid are shown in panels $\mathrm{B}$ and $\mathrm{C}$ respectively. Results are expressed as mean \pm S.D. for at least three triplicate determinations for each treatment group, and statistically significant $(P<0.05)$ induction is indicated with an asterisk.

site in mediating E2 action of the LRP16 gene promoter. However, none of these studies allowed us to identify proteins that interact with this DNA sequence. Therefore, gel mobility shift assays were used to investigate the interactions of nuclear extracts from E2-treated MCF-7 cells with the corresponding ${ }^{32} \mathrm{P}$-labeled oligonucleotides. Since we anticipated that ER $\alpha$ and Spl might bind to the S5p fragment, the consensus ${ }^{32} \mathrm{P}-\mathrm{ERE}$ and ${ }^{32} \mathrm{P}-\mathrm{Spl}$ probes were used as positive controls and antibodies against Er $\alpha$, and Spl proteins were included in separate binding reactions. As shown in Fig. 5A, nuclear extracts from the MCF-7 cell line bound ${ }^{32} \mathrm{P}-\mathrm{ERE}$ or ${ }^{32} \mathrm{P}-\mathrm{S} 5 \mathrm{p}$ to yield a major low-mobility DNA/protein complex, as indicated by the arrow (lanes 2 and 7). Competition with a 100-fold excess unlabeled ERE oligonucleotide markedly decreased the intensity of this band (lanes 3 and 8), but the intensity of this band was unaffected by a nonspecific immunoglobulin (Ig) antibody (lanes 5 and 10). Unexpectedly, the supershifted band was not clearly detected in either lane 4 or 9 after coincubation of nuclear extracts and ${ }^{32} \mathrm{P}$-labeled probe with an Era-specific antibody. Figure 5B shows the results of a gel mobility shift assay to identify $\mathrm{Spl}$ protein. Nuclear extracts from E2-treated MCF-7 cells bound ${ }^{32} \mathrm{P}-\mathrm{Spl}$ oligonucleotides to give several bands (lane 2), and a major low-mobility Sp 1-32P-Spl complex (indicated by an arrow) was observed (lanes 2, 4, 5 and $6)$. This latter band was significantly decreased after competition with 100-fold excess, unlabeled, consensus Spl oligonucleotide (lane 3), but was unaffected by adding mutant, unlabeled Spl oligonucleotide (lane 4) and after coincubation with nonspecific IgG antibody (lane 6). However, Spl antibody supershifted the complex to give a retarded band (lane 5). Lane 8 showed that only the major low-mobility band formed by nuclear extract $-{ }^{32} \mathrm{P}-\mathrm{S} 5 \mathrm{p}$ interaction was similar to that observed with ${ }^{32} \mathrm{P}-\mathrm{Sp} 1$. The specifically bound Sp $1-{ }^{32} \mathrm{P}-$ S5p complex was decreased by nonlabeled, 100-fold excess Sp1 and S5p oligonucleotides (lanes 9 and 10). Although the Sp1-32P-S5p complex in lane 12 appeared to be 'fainter' than that in lane 8 , an effect possibly caused by the loading amount, it was not shifted after coincubation with nonspecific IgG antibody, while Sp1 antibody supershifted the mobility to give a smear-like complex (lane 11), and this site was similar to that observed in lane 5 .

Although our gel mobility shift experiments using MCF-7 nuclear extracts suggested that Spl was involved in regulation of the LRP16 gene expression, they did not provide convincing evidence that the $\mathrm{ER} \alpha$ was involved in formation of a protein-DNA complex. However, to our knowledge, few studies have provided evidence that 


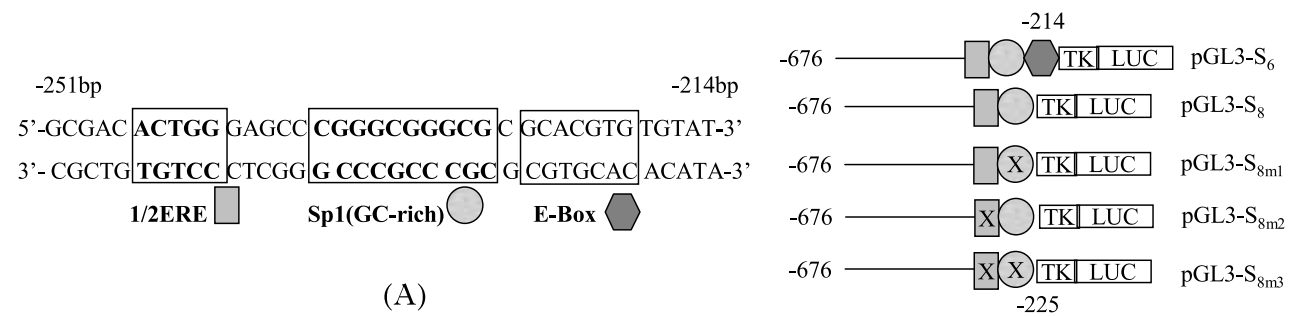

$\mathrm{X}$ Mutant $1 / 2$ ERE $\mathrm{X}$ Mutant Sp1 site

(B)

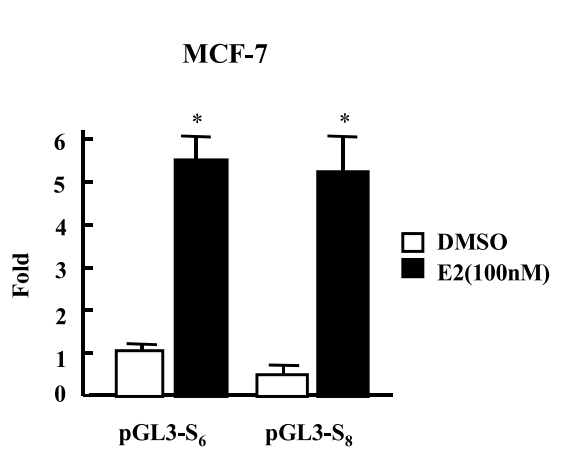

(C)

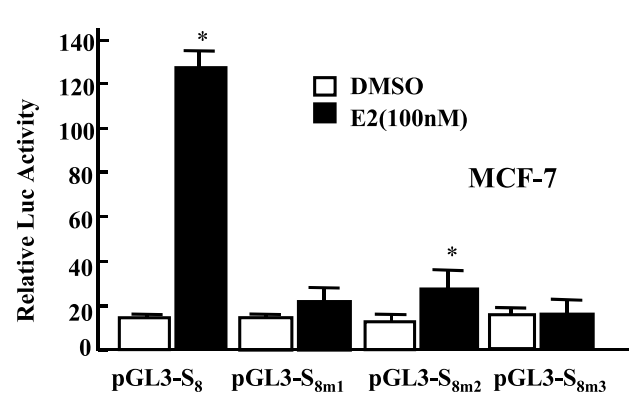

(E)

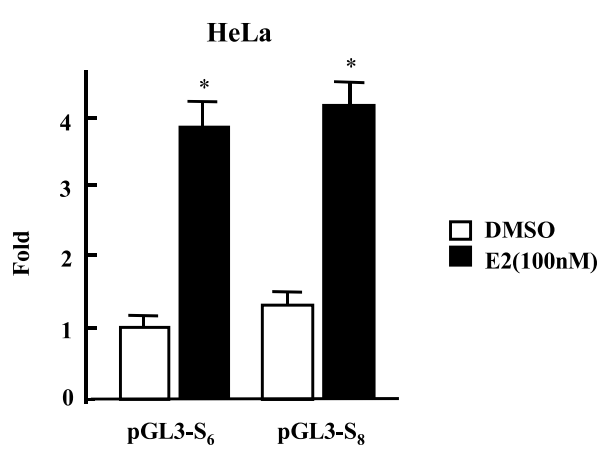

(D)

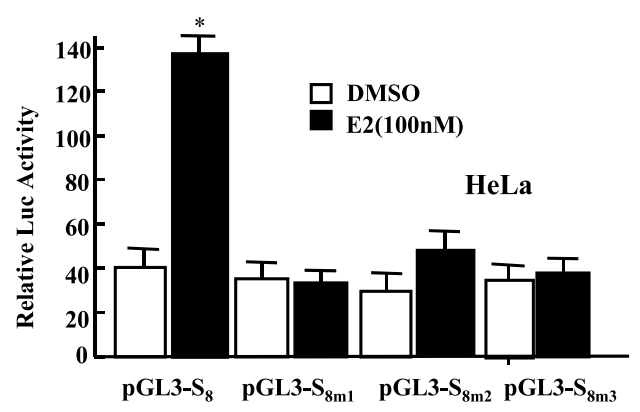

(F)

Figure 4 Luciferase assays with deletion and mutations of the minimal $38 \mathrm{bp}$ fragment for E2-induced transactivation of pGL3-S 6 in MCF-7 and HeLa cells. Sequences of the ERE1/2 site, GC-rich Sp1 binding site and E-box site contained within the 38 bp fragment of -251 to -214 are shown in panel $A$. The rectangle, circle and hexagon represent the ERE1/2, GC-rich region and E-box respectively. The structures of a set of deletion and mutation constructs are shown in panel B, MCF-7 (panels C and E) and HeLa cells (panels D and F). Cells were transiently transfected with various constructs and $1 \mu \mathrm{g}$ human ER $\alpha$ expression plasmid, as described in Fig. 2. Results were expressed as mean \pm S.D. for at least three triplicate determinations for each treatment group, and statistically significant $(P<0.05)$ induction is indicated with an asterisk.

ER from MCF-7 nuclear extracts other than purified or in vitro translated $\mathrm{ER} \alpha$ directly bind to DNA in gel mobility shift assays due to the formation of fragile protein-DNA complexes (Porter et al. 1996, Sun et al. 1998, Petz \& Nardulli 2000). Therefore, gel mobility shift assays were performed with purified ER $\alpha$ and Sp1 proteins. The results, as indicated in Fig. $5 \mathrm{C}$ and D, showed that the major protein-DNA complex was formed by ER $\alpha-{ }^{32} \mathrm{P}-\mathrm{S} 5 \mathrm{p}$ or Sp1-32P-S5p (lane 2), and the band was supershifted by the ER $\alpha$ - or Spl-specific antibody (lane 3), but was not affected by nonspecific IgG (lane 4). Thus, these results suggest that the $1 / 2$ 


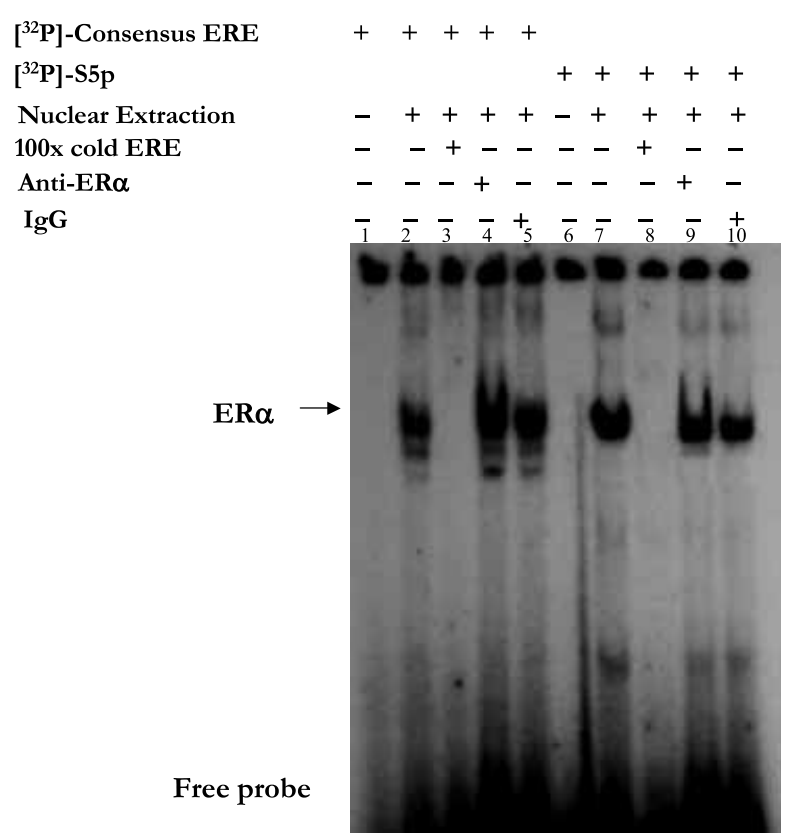

(A)

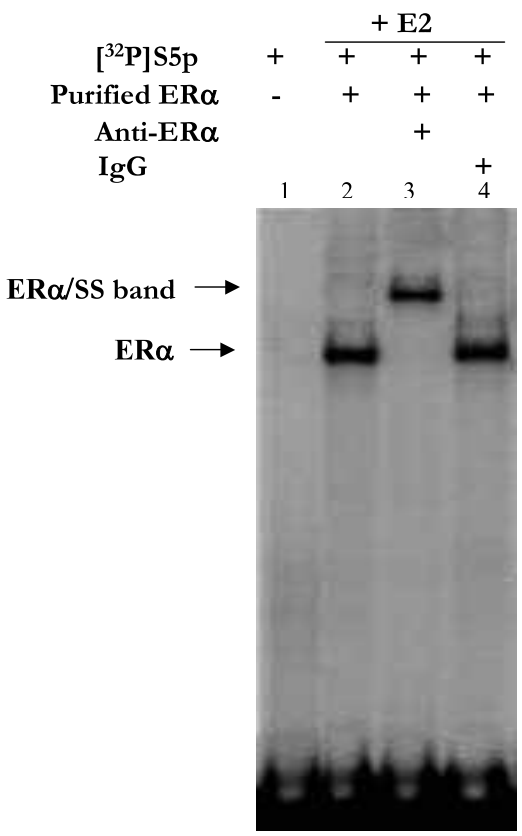

(C)

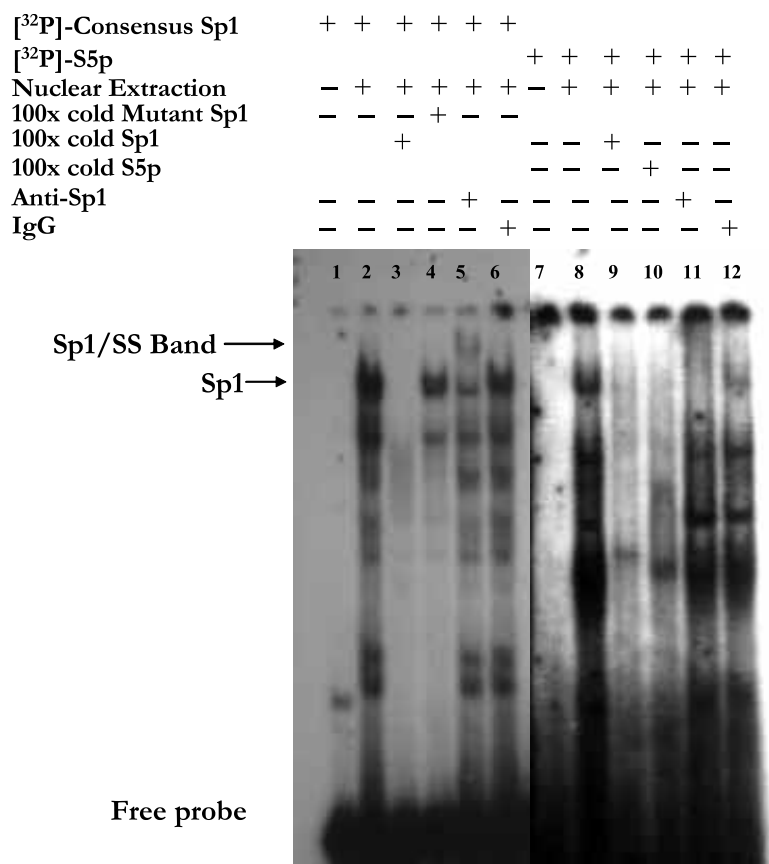

(B)

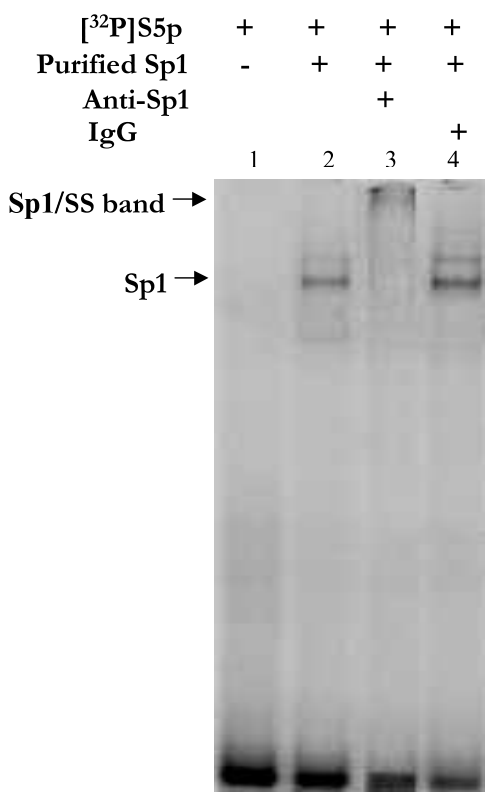

(D)

Figure 5 Gel mobility shift assays of S5p and ER $\alpha$ or Sp1 protein. (A) Binding to ER $\alpha$ protein. Nuclear extracts from MCF-7 cells treated with $100 \mathrm{nM}$ E2 were incubated with ${ }^{32} \mathrm{P}$-labeled consensus ERE or ${ }^{32} \mathrm{P}$-labeled S5p (containing the ERE1/2/Sp1 motif ( -254 to -224$)$ region of the LRP16 gene promoter) and unlabeled wide-type consensus ERE or unlabeled S5p oligonucleotides, ER $\alpha$ antibody or nonspecific IgG, as described in Materials and methods. (B) Binding of Sp1 to ${ }^{32} \mathrm{P}$-labeled consensus Sp1 or ${ }^{32}$ P-labeled S5p in MCF-7 cells. Nuclear extracts from MCF-7 treated with 100 nM E2 were incubated with wild-type or mutant ${ }^{32} \mathrm{P}$-labeled consensus Sp1 and unlabeled wide-type or mutant ${ }^{32} \mathrm{P}$-labeled consensus Sp1, and ${ }^{32} \mathrm{P}$-labeled S5p or unlabeled S5p or wild-type consensus Sp1, Sp1 antibody or nonspecific IgG, as described in Materials and methods. (C) ${ }^{32}$ P-labeled S5p oligos binding to purified ER $\alpha$ protein. We incubated $200 \mathrm{fmol}$ purified ER $\alpha$ protein treated with $20 \mathrm{nM}$ with ${ }^{32} \mathrm{P}$-labeled S5p and ER $\alpha$ antibody or nonspecific IgG. (D) ${ }^{32} \mathrm{P}$-labeled S5p oligos binding to purified Sp1 protein. 

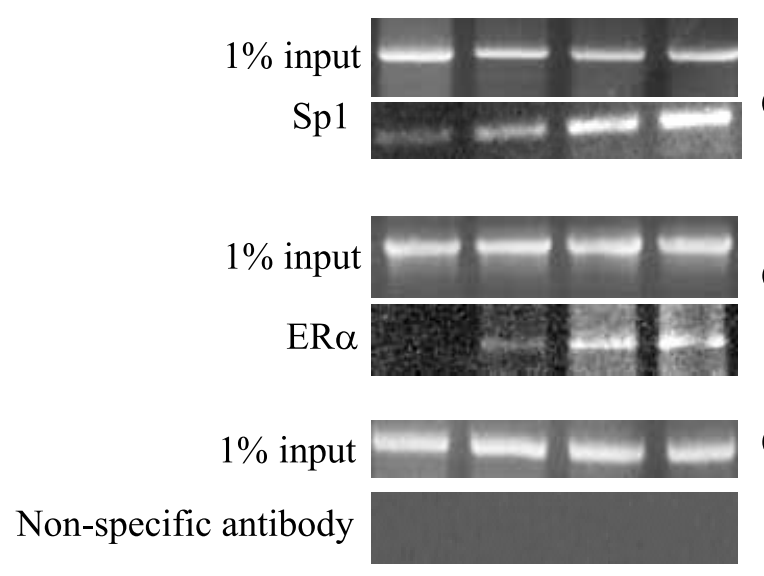

(C)

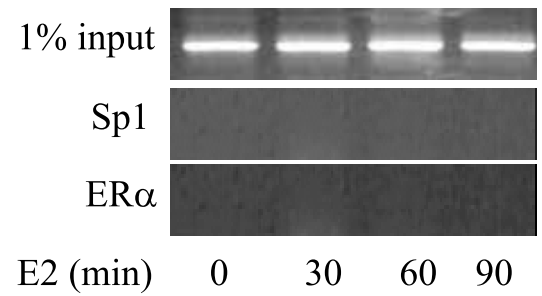

(D)

Figure 6 Analysis by ChIP of ER $\alpha$ and Sp1 interactions with the $5^{\prime}$-flanking sequence of the LRP16 gene. (A-C) The -329 to -210 region of the LRP16 gene promoter. MCF-7 cells were treated with $100 \mathrm{nM}$ E2 for different time points; after immunoprecipitation of cross-linked complexes by Sp1 (A), $\mathrm{ER} \alpha(\mathrm{B})$ antibody or nonspecific IgG $(\mathrm{C})$, the chromatin was analyzed by PCR, as described in Materials and methods. (D) The third exon region of the LRP16 gene. After immunoprecipitation by Sp1 or ER $\alpha$ antibody, the third exon region of the LRP16 gene was detected by PCR, as described in Materials and methods.

ERE-Sp1 site (-246 to $-227 \mathrm{bp})$ in the LRP16 gene promoter directly binds to $\mathrm{ER} \alpha$ and $\mathrm{Sp} 1$ proteins.

Interactions of $\mathrm{ER} \alpha$ and $\mathrm{Sp} 1$ proteins with the LRP16 gene promoter were also investigated in MCF-7 cells treated with $100 \mathrm{~nm}$ E2, using chromatin immunoprecipitation (ChIP) assays (Fig. 6). Cells were treated with E2 for different time points and then cross-linked with formaldehyde. Nuclear extracts were sonicated and immunoprecipitated with $\mathrm{ER} \alpha$ and $\mathrm{Sp} 1$ antibodies. The interaction of ER $\alpha$ and $\mathrm{Sp} 1$ proteins with the proximal region of the LRP16 gene promoter (-356 to $-210 \mathrm{bp})$ was determined by PCR. Spl antibodies immunoprecipitated this region of promoter in untreated MCF-7 cells and in cells treated with $100 \mathrm{~nm}$ E2 for 30, 60 and 90 min (Fig. 6A). ER $\alpha$ antibody did not immunoprecipitate this region of the promoter at $0 \mathrm{~min}$; however, $\mathrm{ER} \alpha$ antibodies gave bands at the 30-, 60- and 90-min time points (Fig. 6B). These data show that interactions of $\mathrm{ER} \alpha$ and Spl with the human LRP16 gene promoter occur at 30-, 60- and 90-min time points after treatment with E2, and indicate a hormone-induced increase in $\mathrm{ER} \alpha$ interactions with the LRP16 gene promoter. As a control experiment, the fragment of -356 to $-210 \mathrm{bp}$ was not detected in the nonspecific IgG group (Fig. 6C). In other negative control experiments, ER $\alpha$ and Spl antibodies did not immunoprecipitate the third exon region of LRP16 gene (Fig. 6D). These data confirm the site of interactions of $\mathrm{ER} \alpha$ and $\mathrm{Spl}$ with the human LRP16 gene promoter in E2-treated MCF-7 cells.

\section{Discussion}

A number of studies have demonstrated that breast cancer is a hormone-dependent multistep process. Although estrogens have been shown to play a central role in breast cancer development, their carcinogenicity in human breast epithelial cells has not yet been clearly demonstrated. An important pathway for the action of estrogen on the target cells is perhaps mediated via ER $\alpha$ and ER $\beta$, which function as ligand-activated transcription factors regulating gene expression as specific EREs in the gene promoter region (Katzenellenbogen \& Katzenellenbogen 2000). Originally, the human LRP16 gene was isolated from lymphocytes in order to identify a leukemia relapse-related gene, but there was no difference between patients primarily diagnosed with acute myeloid leukemia (AML) and patients relapsed, with regard to AML, to LRP16 mRNA expression levels as determined by semiquantitative RT-PGR (Han et al. 2002). By computer-aided SAGE (serial analysis of gene expression) pattern analysis of LRP16 gene in MCF-7 cells, we have demonstrated that E2 induced five- to eightfold increases in LRP16 mRNA levels in MCF-7 cells, and this effect was observed as early as $3 \mathrm{~h}$ after addition of E2. Furthermore, we found that overexpression of the human LRP16 gene markedly increased the protein level of cyclin E in MCF-7 cells; more significantly, it stimulated MCF-7 cell proliferation (Han et al. 2003a). Some recent results also demonstrated that inhibition of LRP16 gene by small interfering RNA (siRNA) specific to LRP16 restrained proliferation in MCF-7 cells (not published). All these data not only demonstrated that LRP16 is a novel E2-regulated gene, but also implied that the LRP16 gene may play an important role in the carcinogenesis and/or progression of hormone-dependent breast cancer.

E2 leads to increases in LRP16 mRNA levels in MCF-7 cells and also in reporter gene activities in MCF-7 and COS-7 cells transfected with pGL3-S construct, which contains a $2.6 \mathrm{~kb}$ insert upstream of the translation starting site of LRP16 gene, as previously reported (Han et al. 2003a,b). These data indicate that regulation of LRP16 gene expression by E2 occurs at the level of transcription.

In the present study, we attempted to identify the E2-responsive regions and functional enhancer elements within the $2.6 \mathrm{~kb}$ promoter region of the LRP16 gene 
that are essential for E2-induced transactivation. Results of computer-aided analysis demonstrated that the fragment of -2623 to $-24 \mathrm{bp}$ does not contain a perfect palindrome ERE, but does contain 10 ERE1/2 sites densely distributed within the region of -2.5 to $-1.8 \mathrm{~kb}$ (data not shown). Interestingly, deletion of the region of -2.6 to $-1.8 \mathrm{~kb}$ did not decrease reporter gene activity. In contrast, its deletion increased $\mathrm{E} 2$ responsiveness (pGL3-S ${ }_{0}$ vs pGL3-S ${ }_{2}$ ). Therefore, it is unlikely that these ERE1/2 sites strongly contribute to E2 action, although E2-liganded ER $\alpha$ might interact with dense ERE1/2 sites, as deduced by Driscoll et al. (1998). Deletion analysis of -2623 to $-24 \mathrm{bp}$ identified the potential negative regulatory sequence within the $-2.6 \mathrm{~kb}$ to $-2 \cdot 2 \mathrm{~kb}$ region. From further deletion and mutation analyses of the LRP16 gene promoter, we characterized a proximal E2-responsive region of -676 to $-214 \mathrm{bp}$, and a $38 \mathrm{bp}(-251$ to $-214 \mathrm{bp})$ fragment was found to be indispensable for E2-induced action conferred by pGL3-S 6 (-676 to $-214 \mathrm{bp})$. Two positively acting elements were found in this $38 \mathrm{bp}$ fragment: an ERE1/2 site in the region of -246 to $-242 \mathrm{bp}$ and an Spl-binding motif in the region of -236 to $-227 \mathrm{bp}$.

In the $38 \mathrm{bp}$ fragment mentioned above, a conserved E-box motif (GCACGTG), which matches the consensus sequence CANNTG, was found in the region of -225 to $-219 \mathrm{bp}$. Such motifs have been reported to be potential binding sites for basic helix-loop-helix (bHLH) transcription factors, c-myc, Myo $\mathrm{D}$, and ubiquitous transcription factors USF-1 and USF-2 proteins (Maekawa et al. 1991, Hoffman \& Chernak 1995, Elnitski et al. 1997, Gao et al. 1997, Gupta et al. 1997, Scholtz et al. 1997). Previous studies have demonstrated that E2 transiently induces $c-m y c$ gene expression in MCF-7 cells, and a synthetic antisense c-myc oligonucleotide partially inhibited E2-induced growth of MCF-7 cells (Dubik et al. 1987, Watson et al. 1991). Xing and coworkers also demonstrated that ER mediates recruitment of USF1/2 to the major late promoter element in the proximal -210 to $-101 \mathrm{bp}$ region of the cathepsin D gene, and that hormones stimulate E-box-dependent transactivation in human breast cancer cells (Xing \& Archer 1998). Although USF1/2 was found to be recruited to the +54 to +78 bp E-box in the trifunctional carbamylphosphate synthetase/ aspartate carbamyltransferase/dihydroorotase (CAD) gene promoter, E2-stimulated transcription was not affected by deletion of this motif (Khan et al. 2003). In our study, deletion of the E-box did not result in diminution of the E2-stimulated reporter gene activity driven by the LRP16 gene promoter region of -676 to -251 bp either in MCF-7 cells or in HeLa cells (Fig. 4C and D).

Spl was originally described as a trans-acting factor that binds to a GG-box (5'-GGGGGG) (Dynan \& Tjian 1983, Gidoni et al. 1984). Subsequent comparison of numerous Spl binding sites led to identification of a higher affinity, consensus Sp1 site, 5'-KYGGCGKRRY3' (Briggs et al. 1986), and the discovery that sequences varying from this consensus sequence displayed decreased affinity for Spl. The GG-rich Spl binding motif found in the promoter region of the LRP16 gene is CGGGGGGGGG (-236 to $-227 \mathrm{bp}$ ) (Fig. 4A). It includes a typical GG-box (GGGGGG). Indeed, in the present case, substitution of two bases $(-234$ to $-235 \mathrm{bp}$, GG to AA) within the Spl-binding motif significantly reduced the effectiveness of E2 to levels approaching background in both MCF-7 and HeLa cells (Fig. 4E and F). Several reports have demonstrated that there is functional synergy between transcription factor $\mathrm{Sp} 1$ and the estrogen receptors, and that estrogen can modulate target gene expression through ER-enhanced Spl binding (Cavailles et al. 1993, Augereau et al. 1994, Paech et al. 1997, Porter et al. 1997, Scholz et al. 1998, Petz \& Nardulli 2000, Samudio et al. 2001). Substitutive mutation of the ERE1/2 site flanking the Spl-binding region also markedly decreased the E2induced responsiveness to 2- and 1.5-fold that of the basal levels in MCF-7 and HeLa cells respectively. These data indicate that the Spl site cannot effectively confer E2 action without its upstream ERE1/2 site, and suggest that synergic interaction of ER $\alpha$ and $\mathrm{Sp} 1$ requires direct binding of $\mathrm{E} 2$-liganded $\mathrm{ER} \alpha$ to the ERE1/2 site.

The classic mechanism of ER $\alpha$ action is associated with estrogen-induced formation of a nuclear homodimer, binding to the ERE of a perfect or imperfect palindrome in target gene promoters, and interaction with other nuclear proteins and general transcription factors to activate gene expression (Driscoll et al. 1998, Klinge 2001). E2-dependent transactivation via ER $\alpha$ -Spl interactions has been characterized in the promoters of several E2-responsive genes, including bcl-2, c-myc, cathepsin $\mathrm{D}$, transforming growth factor $\alpha$ $(\mathrm{TGF} \alpha)$, progesterone receptor, retinoic acid receptor $\alpha 1$, heat-shock protein 27, and others (Cavailles et al. 1989, Krishnan et al. 1994, Porter et al. 1996, Sun et al. 1998, Dong et al. 1999, Petz \& Nardulli 2000). Transactivation of target genes through interaction of $\mathrm{ER} \alpha$ and $\mathrm{Sp} 1$ is mediated by at least two pathways: 1 . interactions of the $\mathrm{ER} \alpha-\mathrm{Spl}$ complex with GG-rich sites in which only $\mathrm{Spl}$ protein binds DNA; 2. interaction of Er $\alpha-\mathrm{Sp} 1$ proteins with $1 / 2 \mathrm{ERE}(\mathrm{N}) \mathrm{xSp} 1$ or $\operatorname{Spl}(\mathrm{N}) x E R E(1 / 2)$ motif DNA elements, where both $\mathrm{ER} \alpha$ and Spl bind DNA elements. In this study, interactions of $\mathrm{Er} \alpha-\mathrm{Spl}$ with $1 / 2 \mathrm{ERE}(\mathrm{N}) \mathrm{xSp} 1$ have been analyzed by gel mobility shift assays to give a broad, retarded band that binds both proteins, and to exhibit the expected supershifted band by using purified proteins. The results of gel mobility shift assays indicate that the ER $\alpha$ and $\mathrm{Sp} 1$ proteins directly bind well to the DNA elements (Fig. 5). 
Previous studies have demonstrated that ER $\alpha$ and Spl physically interact, and ER $\alpha$ preferentially binds to the C-terminal DNA binding domain of Spl protein (Porter et al. 1997), the region that is also required for other transcription factors (Karlseder et al. 1996, Lin et al.1996). Our study investigated the interactions of $\mathrm{ER} \alpha$ and Sp 1 transcription factors with the LRP16 gene promoter, using a ChIP assay in MCF-7 cells at different time points after E2 treatment (Fig. 6). ER $\alpha$ and Sp1 antibodies immunoprecipitate the E2-responsive region (-329 to $-210 \mathrm{bp}$ ) of the LRP16 promoter after treatment with E2 at 30,60 and 90 min (Fig. 6A and B). The above-mentioned fragment was also immunoprecipitated at 0 min when $\mathrm{Spl}$ antibody was used, but not when $\mathrm{ER} \alpha$ antibody was used. The results shown in Fig. 6 indicate that $\mathrm{Spl}$ association with the LRP16 gene promoter is ligand-independent, whereas $\mathrm{ER} \alpha$ interaction is ligand-dependent. It is not surprising to observe that the functional interaction between Spl and ER $\alpha$ in transcriptional regulation of the LRP16 gene expression is ligand-dependent. Several reporters have well established the mechanisms of hormonal regulation of such genes as cad, progesterone receptor, transforming growth factor $\alpha$ and low-density lipoprotein receptor, in which DNA-dependent or -independent interactions of $\mathrm{ER} \alpha$ and $\mathrm{Sp} 1$ proteins are hormone-dependent (Vyhlidal et al. 2000, Li et al. 2001, Khan et al. 2003, Petz et al. 2004).

In summary, the results presented demonstrate that hormonal regulation of LRP16 gene expression is linked to liganded ER $\alpha$ and $\mathrm{Sp} 1$ interactions with an ERE1/2 and GG-rich site in the LRP16 promoter. Many of the genes, such as cyclin D1, E2F1, c-fos and bcl-2, which are regulated by Era-Spl in ER-positive breast cancer cells, play a role in cell proliferation. Our previous study found that the LRP16 gene is also involved in this cellular process (Han et al. 2003a). These observations are consistent with a recent report showing that siRNA for Spl inhibits hormone-induced cell cycle progression in MCF-7 cells (Abdelrahim et al. 2002), and indicate that the LRP16 gene may play an important regulation role in breast cancer development and progression.

\section{Acknowledgements}

We are deeply grateful to Dr Hajime Nawata of Kyushu University, Japan, for his kind donation of the nuclear receptor expression vectors. We sincerely thank Dr David A Hart of the University of Calgary, Canada, for his critical reading of the manuscript. This work was supported by the National Natural Science Foundation of China (grant nos. 30200095 and 30471990) and the National Basic Research Program of China (G2000057008).

\section{References}

Abdelrahim M, Samudio I, Smith R, Burghardt R \& Safe S 2002 Small inhibitory RNA duplexes for Spl mRNA block basal and estrogen-induced gene expression and cell cycle progression in MCF-7 breast cancer cells. Fournal of Biological Chemistry 277 28815-28822.

Augereau P, Miralles F, Cavailles V, Gaudelet C, Parker M \& Rochefort H 1994 Characterization of the proximal estrogen-responsive element of human cathepsin D gene. Molecular Endocrinology 8 693-703.

Briand P \& Lykkesfeldt AE 2001 An in vitro model of human breast carcinogenesis: epigenetic aspects. Breast Cancer Research and Treatment 65 179-187.

Briggs MR, Kadonaga JT, Bell SP \& Tjian R 1986 Purification and biochemical characterization of the promoter-specific transcription factor, Spl. Science 234 47-52.

Brooks SC, Locke ER \& Soule HD 1973 Estrogen receptor in a human cell line (MCF-7) from breast carcinoma. Fournal of Biological Chemistry 248 6251-6253.

Castro-Rivera E, Samudio I \& Safe S 2001 Estrogen regulation of cyclin Dl gene expression in ZR-75 breast cancer cells involves multiple enhancer elements. Fournal of Biological Chemistry 276 30852-30861.

Cavailles V, Augereau P \& Rochefort H 1993 Cathepsin D gene is controlled by a mixed promoter, and estrogens stimulate only TATA-dependent transcription in breast cancer cells. PNAS 90 203-207.

Chow J, Tobias JH, Colston KW \& Chambers TJ 1992 Estrogen maintains trabecular bone volume in rats not only by suppression of bone resorption but also by stimulation of bone formation. Fournal of Clinical Investigation 89 74-78.

Dickson RB \& Lippman ME 1995 Growth factors in breast cancer. Endocrinology Reviews 16 559-589.

Dong L, Wang W, Wang F, Stoner M, Reed JC, Harigai M, Samudio I, Kladde MP, Vyhlidal C \& Safe S 1999 Mechanisms of transcriptional activation of bcl-2 gene expression by 17 beta-estradiol in breast cancer cells. Fournal of Biological Chemistry 274 32099-32107.

Driscoll MD, Sathya G, Muyan M, Klinge CM, Hilf R \& Bambara RA 1998 Sequence requirements for estrogen receptor binding to estrogen response elements. Fournal of Biological Chemistry $\mathbf{2 7 3}$ 29321-29330.

Dubik D, Dembinski TC \& Shiu RP 1987 Stimulation of c-myc oncogene expression associated with estrogen-induced proliferation of human breast cancer cells. Cancer Research 47 6517-6521.

Dynan WS \& Tjian R 1983 The promoter-specific transcription factor Spl binds to upstream sequences in the SV40 early promoter. Cell 35 78-87.

Elnitski L, Miller W \& Hardison R 1997 Conserved E boxes function as part of the enhancer in hypersensitive site 2 of the beta-globin locus control region. Role of basic helix-loop-helix proteins. Fournal of Biological Chemistry 272 369-378.

Farhat MY, Lavigne MC \& Ramwell PW 1996 The vascular protective effects of estrogen. FASEB Fournal 10 615-624.

Finlin BS, Gau CL, Murphy GA, Shao H, Kimel T, Seitz RS, Chiu YF, Botstein D, Brown PO, Der CJ, Tamanoi F, Andres DA \& Perou CM 2001 RERG is a novel ras-related, estrogen-regulated and growth-inhibitory gene in breast cancer. Fournal of Biological Chemistry 276 42259-42267.

Gao E, Wang Y, Alcorn JL \& Mendelson CR 1997 The basic helix-loop-helix-zipper transcription factor USF1 regulates expression of the surfactant protein-A gene. Fournal of Biological Chemistry 272 23398-23406.

Gidoni D, Dynan WS \& Tjian R 1984 Multiple specific contacts between a mammalian transcription factor and its cognate promoters. Nature 312 409-413. 
Gupta MP, Amin CS, Gupta M, Hay N \& Zak R 1997 Transcription enhancer factor 1 interacts with a basic helix-loop-helix zipper protein, Max, for positive regulation of cardiac alpha-myosin heavy-chain gene expression. Molecular Cell Biology 17 3924-3836.

Han WD, Lou FD, Yu L, Wang QS, Han XP \& Li XJ 2002 SAGE pattern of LRP16 gene and its expression in normal blood and leukemic cells. Academic Journal of PLA Postgraduate Medical School 23 $161-163$.

Han WD, Mu YM, Lu XC, Li XJ, Yu L, Song HJ, Li M, Lu JM, Zhao YL \& Pan CY $2003 a$ Up-regulation of LRP16 mRNA by $17 \beta$-estradiol through activation of estrogen receptor $\alpha(\alpha \operatorname{R} \alpha)$, but not estrogen receptor $\beta(\alpha R \beta)$, promotes human breast cancer MCF-7 cell proliferation: a preliminary report. Endocrine-Related Cancer 10 215-222.

Han WD, Li XL, Lu XC, Xu ZM, Yu L, Li M \& Mu YM $2003 b$ Effect of LRP16 on breast cancer MCF-7 cell proliferation. Chinese fournal of Biochemistry and Molecular Biology 19 672-676.

Hoffman PW \& Chernak JM 1995 DNA binding and regulatory effects of transcription factors SP1 and USF at the rat amyloid precursor protein gene promoter. Nucleic Acids Research $\mathbf{2 3}$ 2229-2235.

Karlseder J, Rotheneder H \& Wintersberger E 1996 Interaction of Spl with growth- and cell cycle-regulated transcription factor E2F. Molecular Cell Biology 16 1659-1667.

Katzenellenbogen BS \& Katzenellenbogen JA 2000 Estrogen receptor transcription and transactivation: estrogen receptor alpha and estrogen receptor beta: regulation by selective estrogen receptor modulators and importance in breast cancer. Breast Cancer Research 2 335-344.

Khan S, Abdelrahim M, Samudio I \& Safe S 2003 Estrogen receptor/Spl complexes are required for induction of cad gene expression by 17 beta-estradiol in breast cancer cells. Endocrinology $1442325-2335$.

Klinge CM 2001 Estrogen receptor interaction with estrogen response elements. Nucleic Acids Research 29 2905-2919.

Krishnan V, Wang X \& Safe S 1994 Estrogen receptor-Spl complexes mediate estrogen-induced cathepsin D gene expression in MCF-7 human breast cancer cells. Fournal of Biological Chemistry $26915912-15917$.

Levenson AS \& Jordan VC 1997 MCF-7: the first hormone-responsive breast cancer cell line. Cancer Research $\mathbf{5}$ 73071-73078.

Li C, Briggs MR, Ahlborn TE, Kraemer FB \& Liu J 2001 Requirement of $\mathrm{Spl}$ and estrogen receptor $\alpha$ interaction in $17 \beta$-estradiol-mediated transcriptional activation of the low density lipoprotein receptor gene expression. Endocrinology 142 1546-1553.

Lin SY, Black AR, Kostic D, Pajovic D, Hoover CN \& Azizkhan JC 1996 Cell cycle-regulated association of E2F1 and $\mathrm{Sp} 1$ is related to their functional interaction. Molecular Cell Biology 16 1668-1675.

Lippman ME, Bolan G \& Huff K 1975 Human breast cancer responsive to androgen in long term tissue culture. Nature $\mathbf{2 5 8}$ 339-341.

Maekawa T, Sudo T, Kurimoto M \& Ishii S 1991 USF-related transcription factor, HIV-TF1, stimulates transcription of human immunodeficiency virus-1. Nucleic Acids Research 19 4689-4694.

Paech K, Webb P, Kuiper GG, Nilsson S, Gustafsson J, Kushner PJ \& Scanlan TS 1997 Differential ligand activation of estrogen receptors ERalpha and ERbeta at AP1 sites. Science $\mathbf{2 7 7}$ $1508-1510$

Petz LN \& Nardulli AM 2000 Spl binding sites and an estrogen response element half-site are involved in regulation of the human progesterone receptor A promoter. Molecular Endocrinology 14 972-985.

Petz LN, Ziegler YS, Loven MA \& Nardulli AM 2002 Estrogen receptor alpha and activating protein- 1 mediate estrogen responsiveness of the progesterone receptor gene in MCF-7 breast cancer cells. Endocrinology 143 4583-4591.
Petz LN, Ziegler YS, Schultz JR, Kim H, Kemper JK \& Nardulli AM 2004 Differential regulation of the human progesterone receptor gene through an estrogen response element half site and Spl sites. Foumal of Steroid Biochemistry and Molecule Biology $\mathbf{8 8}$ 113-122.

Porter W, Wang F, Wang W, Duan R \& Safe S 1996 Role of estrogen receptor/Spl complexes in estrogen-induced heat shock protein 27 gene expression. Molecular Endocrinology 10 1371-1378.

Porter W, Saville B, Hoivik D \& Safe S 1997 Functional synergy between the transcription factor $\mathrm{Spl}$ and the estrogen receptor. Molecular Endocrinology 11 1569-1580.

Qin C, Nguyen T, Stewart J, Samudio I, Burghardt R \& Safe S 2002 Estrogen up-regulation of p53 gene expression in MCF-7 breast cancer cells is mediated by calmodulin kinase IV-dependent activation of a nuclear factor kappaB/CCAAT-binding transcription factor-1 complex. Molecular Endocrinology 16 1793-1809.

Safe S 2001 Transcriptional activation of genes by 17 beta-estradiol through estrogen receptor-Spl interactions. Vitamins and Hormones Advances in Research and Applications 62 231-252.

Samudio I, Vyhlidal C, Wang F, Stoner M, Chen I, Kladde M, Barhoumi R, Burghardt R \& Safe S 2001 Transcriptional activation of deoxyribonucleic acid polymerase alpha gene expression in MCF-7 cells by 17 beta-estradiol. Endocrinology 142 $1000-1008$.

Scholtz B, Kingsley-Kallesen M \& Rizzino A 1996 Transcription of the transforming growth factor-beta2 gene is dependent on an E-box located between an essential cAMP response element/activating transcription factor motif and the TATA box of the gene. Fournal of Biological Chemistry 271 32375-32380.

Scholz A, Truss M \& Beato M 1998 Hormone-induced recruitment of Spl mediates estrogen activation of the rabbit uteroglobin gene in endometrial epithelium. Fournal of Biological Chemistry 273 $4360-4366$.

Soule HD, Vazguez J, Long A, Albert S \& Brennan M 1973 A human cell line from a pleural effusion derived from a breast carcinoma. Fournal of the National Cancer Institute 51 1409-1416.

Sun G, Porter W \& Safe S 1998 Estrogen-induced retinoic acid receptor alpha 1 gene expression: role of estrogen receptor-Sp1 complex. Molecular Endocrinology 12 882-890.

Turner RT, Riggs BL \& Spelsberg TC 1994 Skeletal effects of estrogen. Endocrinology Reviews 15 275-300.

van 't Veer LJ, Dai H, van de Vijver MJ, He YD, Hart AA, Mao M, Peterse HL, van der Kooy K, Marton MJ, Witteveen AT, Schreiber GJ, Kerkhoven RM, Roberts C, Linsley PS, Bernards R \& Friend SH 2002 Gene expression profiling predicts clinical outcome of breast cancer. Nature 415 530-536.

Vyhlidal C, Samudio I, Kladde M \& Safe S 2000 Transcriptional activation of transforming growth factor $\alpha$ by estradiol: requirement for both a GC-rich site and an estrogen response element half-site. Fournal of Molecular Endocrinology 24 329-338.

Watson PH, Pon RT \& Shiu RP 1991 Inhibition of c-myc expression by phosphorothioate antisense oligonucleotide identifies a critical role for c-myc in the growth of human breast cancer. Cancer Research 51 3996-4000.

Xie W, Dnau R, Chen I, Samudio I \& Safe S 2000 Transcriptional activation of thymidylate synthase by $17 \beta$-estradiol in MCF-7 human breast cancer cells. Endocrinology 141 2439-2449.

Xing W \& Archer TK 1998 Upstream stimulatory factors mediate estrogen receptor activation of the cathepsin D promoter. Molecular Endocrinology 12 1310-1321.

Yu L, Han WD, Lou FD, Wang QS \& Zhao Y 2000 Cloning of leukemia associated gene LRP16 in acute myeloid leukemia. Academic Fournal of PLA Postgraduate Medical School 21 81-84.

Received 19 November 2004

Accepted 26 November 2004

Made available online as an Accepted Preprint

6 December 2004 